\title{
An Analysis of the Pre-service Teachers' Teaching Anxiety and Coping Strategies: A Turkish Elementary School Context
}

\author{
Análisis de la ansiedad y estrategias de afrontamiento en \\ profesores en formación: un contexto de escuela primaria \\ turca
}

\author{
Turgay Han and Ayşegül Takkaç Tulgar \\ Ordu University and Atatürk University, Turkey
}

\begin{abstract}
The aim of this study is to investigate the construct of English as a foreign language (EFL) pre-service teachers' feelings of anxiety before, while, and after experiencing teaching English within a Turkish elementary classroom setting. Specifically, this intrinsic qualitative study investigates the anxiety sources for pre-service teachers in their practicum experiences and the ways they adapted to cope with these anxiety-provoking sources. The data were triangulated by consulting three sources of information(e.g., open-ended questions in the self-report forms, open-ended questions in the peerreflection forms, and diaries) relating the 32 participants' practicum experiences. The findings indicated that prior to practicum experience, classroom management was the major teaching anxiety source and the "the most" frequently employed coping strategy was to consult their mentors and cooperating teachers. However, during the actual practicum experience, being observed by a mentor was the most common concern and to cope with it, each participant developed different coping mechanisms. Finally, receiving negative feedback from mentors after the post-practicum experience decreased self-confidence and to compensate, pre-service teachers frequently asked mentors to provide further advice. It is implicated that teacher education programs raise the awareness of pre-service teachers of the potential challenges awaiting them in the practicum experience and equip them with coping strategies.
\end{abstract}

Keywords: Pre-service teachers, teaching anxiety, coping strategies, elementary school, EFL, feedback, practicum experience

1 Received: April 22nd 2019/ Accepted: August 28th 2019

2 turgayhan@yahoo.com.tr; aysegultakkac@hotmail.com 


\section{Resumen}

El objetivo de este estudio es de investigar el constructo de inglés como lengua extranjera (EFL), los sentimientos de los profesores en formación antes, durante y después de experimentar la enseñanza de inglés en un salón de clase de primaria turca. Específicamente, este estudio cualitativo intrínseco investiga las fuentes de ansiedad para los maestros en formación y sus experiencias de práctica y las maneras en que ellos se adaptaron para lidiar con dichas fuentes que provocan la ansiedad. Los datos se triangularon al consultar tres fuentes de información (por ejemplo: preguntas abiertas en formularios de autoinforme y diarios) relacionando las experiencias de práctica de 32 participantes. Los hallazgos indicaron que antes de la experiencia de práctica, el manejo de clase era la fuente de más ansiedad y la estrategia para lidiar con la ansiedad más empleada fue la consulta a mentores y docentes cooperantes. Sin embargo, durante la experiencia de practica real, el ser observados por el mentor era la preocupación más común y para lidiar con esto, cada participante desarrolló diferentes mecanismos para manejarlo. Por último, recibir retroalimentación negativa de los mentores después de la experiencia de práctica posterior disminuyó la auto confianza y para compensarlo, los maestros en formación consultaron con frecuencia a sus mentores para recibir consejos adicionales. Lo anterior implica que los programas de formación docente sensibilicen a los a los docentes en formación sobre los posibles desafíos que les esperan en su práctica y que los doten de estrategias para poder manejar dichos desafíos.

Palabras clave: Docentes en formación, ansiedad de enseñanza, estrategias de afrontamiento, escuela primaria, inglés como segunda lengua, retroalimentación, experiencia de práctica.

\section{Resumo}

O objetivo deste estudo é de pesquisar o construto de inglês como língua estrangeira (EFL), os sentimentos dos professores em formação antes, durante e depois de experimentar o ensino de inglês em uma sala de aula de primária turca. Especificamente, este estudo qualitativo intrínseco pesquisa as fontes de ansiedade para os mestres em formação e suas experiências de prática e as maneiras em que eles se adaptaram para lidar com mencionadas fontes que provocam a ansiedade. Os dados se triangularam ao consultar três fontes de informação (por exemplo: perguntas abertas em formulários de auto-relatório e diários) relacionando as experiências de prática de 32 participantes. As descobertas indicaram que antes da experiência de prática, o manejo de aula era a fonte de mais ansiedade e a estratégia para lidar com a ansiedade mais empregada foi a consulta a mentores e docentes cooperantes. Entretanto, durante a experiência de prática real, o fato de serem observados pelo mentor era a preocupação mais comum, e para lidar com isto cada participante desenvolveu diferentes mecanismos para manejálo. Por último, receber retroalimentação negativa dos mentores depois da experiência de prática posterior diminuiu a autoconfiança e para compensá-lo, os mestres em formação consultaram com frequência a seus mentores para receber conselhos adicionais. $\mathrm{O}$ anterior implica que os programas de formação docente sensibilizem os docentes em formação sobre os possíveis desafios que lhes esperam em sua prática e que os dotem de estratégias para poder manejar mencionados desafios.

Palavras chave: Docentes em formação, ansiedade de ensino, estratégias de afrontamento, escola primária, inglês como segunda língua, retroalimentação, experiência de prática. 


\section{Introduction}

$\mathrm{T}$ The concept of anxiety has attracted much attention in language education because it has played a significant role and has had undeniable effects on the process of teaching and learning (Han \& Aybirdi, 2017). Anxiety is an emotional situation of fear and apprehension (Scovel, 1978). Regarding a specific type of anxiety, Horwitz, Horwitz, and Cope (1986) described Foreign Language Anxiety (FLA) as "a distinct complex construct of self-perceptions, beliefs, feelings, and behaviors related to classroom language learning arising from the uniqueness of language learning process" (p. 128). Oxford (1999) divided anxiety into two parts: facilitative anxiety which is the stimulating force in a positive sense, and debilitative anxiety which is the weakening force in a negative sense. Brown (2000) referred to these two anxiety types as trait anxiety which is related to personality characteristics and state anxiety which is felt in a specific situation.

While some studies have been carried out to investigate sources of anxiety for learners (Aydın, 2008; Elald1, 2016; Gopang, Bughio \& Pathan, 2015), others have investigated the anxiety-provoking factors for teachers (Kesen \& Aydın, 2014; Machida, 2016) because potential challenges and negative feelings experienced in the teaching process can result in teaching anxiety in non-native teachers of a target language, which may, in turn, negatively affect foreign language education (Horwitz, 1996). Teaching anxiety is connected with preparing and conducting teaching activities in real classroom settings (Gardner \& Leak, 1994). As Foreign Language Teaching Anxiety (FLTA) is an emotional state that results from the individual, motivational, and perceptional unease, it can be observed before, during, and after teaching (Aydın, 2016). Foreign language teachers experience teaching anxiety from such sources as classroom management, school-related issues, fear of negative evaluation, and proficiency in using the target language (Azmi, 2012; Machida, 2016). Furthermore, even though foreign language teachers have advanced foreign language proficiency, they can still experience tension and concern in the teaching process (Gregersen, Meza \& MaIntyre, 2014; Horwitz, et al., 1986; Merç, 2015; Yoon, 2012). Compared to native language teachers, foreign language teachers differ in regards to responsibilities they shoulder and challenges they face (Yoon, 2012). The profession may become even more difficult for non-native language teachers who are supposed to teach a language which is not their own language (e.g., Merç, 2011; Yoon, 2012).

FLTA does not only affect in-service teachers; pre-service English-asa-Foreign Language (EFL) teachers who are supposed to attend practicum courses in the final year of their tertiary education can also experience the negative impacts of FLTA. Though they are still learners of the language, they are to experience the transition from being a student to being a teacher 
and practicum is the route through which they can have this initial transition. In this process, their being non-native teachers, being inexperienced in the profession, and being observed by their mentors in their practices can become factors causing anxiety for pre-service teachers and may sometimes have severe consequences on their attitudes towards the profession (Kim \& Kim, 2004; Merç, 2015; Sammephet \& Wanphet, 2013).

The issue of FLTA for pre-service teachers has been an issue of growing attention in different contexts. While the sources of FLTA for pre-service teachers was investigated qualitatively in a Turkish context (Merç, 2011, Paker, 2011, Aydin, 2016), in a Malaysian context (Azmi, 2012), in an Indonesian context (Agustiana, 2014), and in a Thai context (Sammaphet \& Wanphet, 2013; Lampadan, 2014), some other studies have investigated pre-service EFL teachers' coping strategies with FLTA in addition to the challenges (e.g., Lampadan, 2014; Mahmoud \& Özkan, 2016; Sammephet \& Wanphet, 2013).

In light of the relevant literature, although there is growing attention regarding the sources of FLTA for pre-service teachers, there is still a scarcity of research investigating the coping strategies employed by pre-service teachers when they experience FLTA. Furthermore, the sources of FLTA, its effects on pre-service language teachers, and the ways in which these teachers cope with these challenges need an investigation because FLTA is an area in which there is comparatively limited research. Taking this gap into account, this study aims to find out the possible sources of anxiety in the practicum experiences of English-as-a-foreign-language (EFL) pre-service teachers and reveal the ways they try to cope with these challenging cases. This understanding is expected to contribute to EFL pre-service teachers in that it alerts them about the probable problematic cases they are to encounter and equips them with some effective coping strategies to deal with the anxiety-provoking situations. This study is also expected to raise the awareness of the faculty in training the undergraduate students, inform them about the realities of the practicum period and equip them with coping strategies, in effect helping them "survive" the practicum. Therefore, this study aims to bridge this research gap by examining pre-service EFL teachers' FLTA and coping strategies in Turkish research context.

\section{Literature Review}

Research on FLTA has investigated this phenomenon from different angles, which can be presented in mainly two categories: research on sources of FLTA of pre-service teachers (Agustiana, 2014; Aydın, 2016; Azmi, 2012; Merç, 2011; Paker, 2011) and research on sources of and coping ways with FLTA of pre-service teachers (Lampadan, 2014; MacDonald, 1993; Mahmoudi \& Özkan, 2016; Sammephet \& Wanphet, 2013). 


\section{Research on the Sources of FLTA}

The first set of studies are about the sources of FLTA for pre-service teachers. Centering on the sources creating problems for pre-service teachers during practicum, Merç (2011) asked 150 Turkish pre-service teachers to keep diaries during their practicum experience and conducted semi-structured interviews with 30 of these students. The results of the constant comparison analysis showed that learner profile, classroom management, steps to follow in teaching, and observation were the main challenges for the participants . In a study by Paker (2011), the potential anxiety sources for 101 pre-service teachers during teaching practicum in a Turkish context were investigated. In addition, some students also took part in interviews.

The results were similar to those in Merç's (2011) study, revealing that the participants felt anxious because of evaluation, classroom management, and some pedagogical issues. In a study making a comparison between preservice and experienced teachers' stress levels in teaching English, Azmi (2012) worked with 51 pre-service teachers and 38 experienced teachers. Using a questionnaire and semi-structured interviews, the researcher concluded that being observed, unexpected situations, communicative teaching, and student reactions were among the factors of stress for the participants. Both preservice and experienced teachers seemed to feel under the stress of teaching responsibility.

Another study on pre-service teacher anxiety was offered by Agustiana (2014). The researcher, on a qualitative basis, adapted closeended questionnaires and semi-structured interviews to collect data from 50 Indonesian pre-service teachers completing their practicum. Being observed by the cooperating teacher or mentor, lack of experience in teaching, crowded classes, and student questions were the major sources of anxiety for the participants.

Sharing a similar purpose with the above-mentioned studies, Aydın (2016) examined FLTA experienced by 60 Turkish pre-service teachers by collecting data through background questionnaires, interviews, student reflections, and essays. The results showed that being observed, fear of negative evaluation, language proficiency, and inexperience in teaching created stress for the participants. In Aydın's study, the participants were observed to experience teaching anxiety before, during, and after their teaching practices. 


\section{Research on the FLTA Coping Strategies}

The second group of studies focuses on the sources of FLTA and the coping strategies of pre-service teachers with these problems. Exploring stress factors for 11 pre-service teachers during practicum, MacDonald (1993) conducted surveys, focus-group interviews, observations, and asked the participants to keep journals. The results revealed that the teaching practicum was the most stressful phase of the educational lives of the participants. Expectations of students, mentors, and cooperating teachers; time management; being evaluated; and role clarification were among the challenges for the pre-service teachers.

The participants reported that they tried to cope with anxiety through communicating, establishing clear goals, and some relaxation techniques. Aiming to find out the anxiety-generating sources for four Thai pre-service teachers' FLTA and their coping mechanisms with potential problems, Sammephet and Wanphet (2013) used interviews as the main research tool and conducted three interviews with the participants: one, a couple of days before their first teaching, the second, a few days after their first teaching experience, and the third, in the middle of semester. The results showed that personality traits, the context of teaching, and being supervised were the major causes of anxiety with the participants. To cope with these challenges, the participants reported using some anxiety management tactics like self-control, accepting and facing the situation, and dealing with it.

Following a phenomenological approach, Lampadan (2014) carried out individual meetings, observations, and interviews with eight Thai pre-service teachers and concluded that teaching preparation, classroom management, and relationships with different agents were challenging for the participants. The participants were observed to benefit from preparation, adaptation, positive attitude, and developing good relationship with their peers and mentors as coping strategies.

\section{An Overview of Challenges for Language Teachers}

Setting out from the results of existing studies, it can be assumed that there are various sources of FLTA from which in-service and pre-service 54 foreign language teachers suffer. The common challenges for in-service and pre-service language teachers are reported to be related to classroom management issues, unexpected situations or student questions, proficiency in using the target language, and fear of making mistakes or negative evaluation (Agustiana, 2014; Lampadan, 2014; Machida, 2016; Merç, 2011; Paker, 2011). On the other hand, there are also some other factors creating problems for pre-service teachers since they do not have experience in the profession 
(Aydın, 2016, Paker, 2011). In other words, their lack of teaching experience accompanied by the fact that they are observed and evaluated during practicum by mentors, cooperating teachers, and students can create great tension for pre-service teachers and increase their FLTA (Aydın, 2016; MacDonald, 1993; Mahmoudi \& Özkan, 2016 ). In a limited number of studies on the coping strategies (e.g., some anxiety management tactics like self-control, accepting and facing the situation, and setting clear goals) with practicum stress, it is revealed that self-control, accepting and facing the situation (Sammephet \& Wanphet, 2013), and holding positive attitudes and establishing strong ties with peers and mentors (Lampadan, 2014) are the main coping strategies of the pre-service teachers.

The practicum process can be regarded as a pre-stage for pre-service teachers to have a chance to observe and practice foreign language teaching in real classroom environments (Smith, 2010). The experiences in this process are of great significance for the future professional careers of pre-service teachers (Gal, 2006). Revealing the dynamics underlying the anxiety experiences of EFL pre-service teachers can contribute to the betterment of their practicum experiences, in which pre-service teachers can already have an idea of what is awaiting them and therefore, can arm themselves against the possible challenges in the process. In addition, this investigation can help the faculty to train the pre-service teachers in a way that combines theory and practice, raising the undergraduates' awareness of the realities in the practicum experience. In this way, pre-service teachers can have more effective and healthier practicum experiences positively affecting their future teaching experiences.

\section{Method}

This research approaches the issue with an intrinsic qualitative design through triangulation, which helps to provide a deeper understanding of the factors causing teacher FLTA. Stake (1995) describes that researchers who want to understand a particular case deeply use this approach. The case that may have peculiarity or ordinariness becomes the focus of interest. The aim of such a design is not to develop a theory, instead the aim is to better understand intrinsic aspects of the case (cf. Hellström, Nolan, \& Lundh, 2005).

Triangulation is the use of multiple data collection sources for the purpose of minimizing the biases in research and maximizing the validity of the study (Baxter \& Jack, 2008; Denzin, 1989 cited in Flick, 2018). Previous research has also benefitted from interview questions and diaries kept by the participants in the data collection (e.g., Agustiana, 2014; Aydın, 2016; Azmi, 2012; Merç, 2011; Paker, 2011). Therefore, in this present study we used open-ended questions in the self-report forms, open-ended questions in the peer-reflection forms, and diaries to collect data. By doing so, the reliability 
and completeness of the data were triangulated through the use of these three sources of data.

Based on the above-mentioned history of the teacher FLTA research in Turkey and the global stance on the matter, the current research is significant in several ways. Firstly, to the best of our knowledge, no research on the preservice EFL teachers' FLTA factors in a Turkish context has employed three steps in the data collection procedure: before the participants' real teaching experiences in the classroom (e.g., pre-teaching experience), during their teaching experiences, in the classroom contexts, and after their teaching experiences. We selected this research context and the participants because they have been identified as special in the sense of being last-year students in their study programs and have no prior teaching experiences, and the researchers of this study wanted to see if they can find out why they have teaching anxiety and how they overcome their teaching anxiety problem. Secondly, this study used several data collection tools (e.g., self-reports, interview questions, reflections forms and diaries).

\section{Sampling and Recruiting}

A purposeful sampling strategy was followed to portray the different perspectives on the anxiety problem in the first teaching experiences by preservice teachers. This study was conducted with the participation of EFL teacher candidates during the spring semester of their 2016-2017 academic year. EFL teacher candidates who were enrolled in EFL teacher education programs in two different Turkish state universities other than the students in other language-related programs such as translation and interpretations were invited to participate in the study voluntarily because the researchers of this study had close relationships with them as they were our students over 4 years. They were given consent forms for privacy and their previous level of teaching experience and their level of proficiency in English were assumed to be similar because they were classmates.

\section{Participants}

The participants consisted of 32 pre-service English teachers studying at ELT Departments in two state universities in Turkey; 71\% (19) participants were female and 29\% (13) participants were male. The ages of the participants ranged from 20 to 27 . The participants' native language was Turkish and they were assumed to have advanced levels of English proficiency. These participants were fourth grade prospective English teachers who were supposed to attend a 14-week teaching practice at elementary schools of the Ministry of National Education for their teaching practicum. 
During this teaching practicum process, the participants were expected to experience the teaching profession in its authentic context where they could have their initial teaching practices. Therefore, these 32 participants were thought to represent the group of pre-service teachers who could possibly experience foreign language teaching anxiety in their initial teaching experiences. Table 1 summarizes the participants' background before starting to practice teaching at state schools and their first teaching practices. 
Table 1. The learning program of the participants to prepare them to teach

\begin{tabular}{|c|c|c|c|}
\hline Step 1 & $\begin{array}{l}\text { Prior to practicum } \\
\text { experience }\end{array}$ & Setting & Aim \\
\hline $\begin{array}{l}\text { Two } \\
\text { semesters } \\
\text { for } \\
\text { background } \\
\text { gaining (28 } \\
\text { weeks) }\end{array}$ & $\begin{array}{l}\text { Instruction on language } \\
\text { teaching methodology } \\
\text { and techniques, syllabus } \\
\text { design, classroom } \\
\text { management, instructional } \\
\text { material design and testing } \\
\text { and evaluation. }\end{array}$ & University programs & $\begin{array}{l}\text { To prepare the } \\
\text { pre-service } \\
\text { teachers for } \\
\text { the theoretical } \\
\text { background } \\
\text { of language } \\
\text { teaching and } \\
\text { learning before } \\
\text { becoming EFL } \\
\text { teachers. } \\
\end{array}$ \\
\hline Step 2 & $\begin{array}{l}\text { Starting practicum m } \\
\text { experience }\end{array}$ & Setting & Aim \\
\hline 4 weeks & $\begin{array}{l}\text { At the beginning of their } \\
\text { practicum experiences, } \\
\text { they observed } \\
\text { cooperating teachers } \\
\text { at }<\text { in }>\text { classroom settings } \\
\text { and received feedback } \\
\text { regarding their observation } \\
\text { experiences from both } \\
\text { their mentors at schools } \\
\text { and supervisors at the } \\
\text { university. The feedback } \\
\text { was given in a discussion } \\
\text { manner. This step } \\
\text { continued for the next } 4 \\
\text { weeks. }\end{array}$ & $\begin{array}{l}\text { They started to } \\
\text { observe students, } \\
\text { peers, and mentors at } \\
\text { secondary or } \\
\text { elementary state } \\
\text { schools. }\end{array}$ & $\begin{array}{l}\text { To prepare them } \\
\text { to teach. }\end{array}$ \\
\hline Step 3 & Practicum experience & Setting & Aim \\
\hline 8 weeks & $\begin{array}{l}\text { They taught language } \\
\text { topics such as grammar, } \\
\text { speaking, and reading as } \\
\text { presented in student books } \\
\text { and the teacher's book. }\end{array}$ & $\begin{array}{l}\text { They started to teach } \\
\text { at the schools. }\end{array}$ & $\begin{array}{l}\text { To help them } \\
\text { improve } \\
\text { their real-time } \\
\text { teaching skills } \\
\text { and to gain } \\
\text { experience in the } \\
\text { real classroom } \\
\text { context. }\end{array}$ \\
\hline
\end{tabular}




\section{Data Collection}

Prior to collecting the data, the researchers of this study applied for and received a letter of permission from the heads of the departments. Next, the researchers invited the students to participate in the study. The volunteer participants were informed about the study and were given consent forms in which the researchers had stipulated that the participants' safety, privacy, and confidentiality would be strictly taken into consideration and that the collected data would be kept confidential by the researchers. The content of the study was explained and they were given a signed and dated copy of the consent form by the researchers (c.f. Aydın, 2016; Paker, 2011; Sammephet \& Wanphet, 2013).

The data were collected through several instruments. The background questionnaire helped the researchers to obtain information about the participant profiles including their age and gender. The peer observation forms enabled the researchers to understand the perspectives and thoughts of the participants regarding their observations of their peers' performances (see Appendix). With the help of this form, the participants could express how they perceived their peers' facial expressions, their instructional language and their attitudes. In this way, the participants could evaluate the performances of their peers as an outsider.

\section{Background Questionnaire}

The background questionnaire included questions regarding the The background questionnaire included questions regarding the demography of the participants such as gender and age. It was given prior to the study.

\section{Observations}

Observations were made by each pre-service teacher (e.g., participantobservation) and by their peers (e.g., peer-observation). While a pre-service teacher was teaching in a classroom, other participants observed him/her in the same classroom over a 12-week period. Each pre-service teacher lectured one hour each week while the rest of the participants were making observations and taking field notes. During the peer observation, the participant-observers used a simple observation strategy to focus on facial expressions, and language use in the teaching experiences in the authentic classroom atmosphere. Further, in the interviews, observations, and diaries, the participants were directed to focus on the specific details about the problems they encountered and the strategies to cope with them each of pre, while and post authentic teaching experiences. 
In the diaries and self-observation forms, the participants were asked to reflect on their own teaching experiences and focus on the challenges they encountered and how they coped with these problems in the pre-, while- and post-stages of teaching. Peer observation forms and self-observation forms were used to enlighten the participants' FLTA experiences and their coping mechanisms. The participants were asked to fill in the peer observation and self-observation forms immediately after each teaching experience in order not to miss critical points in their observations. With the help of the self-observation forms and diaries, the participants could evaluate their own performances and experiences in the light of the questions in a guided way and in their diaries in an independent way. In this way, they could hold a critical stance regarding their performances as an insider.

The participants recorded field-notes based on day-to-day observations over a 12-week period. A group of participants (e.g. 6-7 participants) entered the different classrooms together each week and one of them lectured while the other students observing and taking notes. The data regarding the perspectives of the participants' teaching experiences were collected through the following three steps:

Before the teaching experiences: The open-ended questions for preteaching experiences focused on their opinions about their first teaching experiences, the problems encountered while preparing to teach and how they try to overcome them.

While-teaching experiences: The open-ended questions for whileteaching experiences were about specific details concerning possible problems encountered, such as classroom management, time management, committing language mistakes, other observers (e.g., mentor, supervisors, peers) and their immediate strategies to overcome such problems.

Post-teaching experiences: The open-ended questions for post-teaching experiences focused on other potential factors that cause anxiety such as supervisor feedback, grading the teaching performance, their wishes about the past experience and evaluations on how to cope with such sources of anxiety.

\section{The interviews}

The researchers also conducted interviews with the participants. The intervThe researchers also conducted interviews with the participants. The interview questions were prepared in the light of previous literature on teacher FLTA and the conversations between the participants and researchers. The participants were mainly asked questions about the challenging cases creating anxiety in their teaching experiences and how they tried to cope with these challenges. The interview questions were though to cross-check the answers 
the participants provided in the other instruments. The interviews were mostly done in the native language of the participants to convey feelings more effectively. Each interview lasted 15/20 minutes. The interview records were translated into English and proofread by a native speaker.

\section{Diaries}

The last instrument was participant diaries. The pre-service teachers were asked to keep diaries over a 12-week period in which they reflected on their teaching experiences considering the sources of anxiety and their coping strategies. The participants were told that they were free to comment on any particular experience or on their overall evaluations of their teaching instances. The aim in asking the participants to keep diaries was to ensure that they could narrate their FLTA experience from any perspective that they desired for.

These instruments were all adopted to triangulate the data and to increase data trustworthiness. With the help of these instruments, the participants could adopt the perspectives of insider and outsider in the process of evaluating their practicum experiences taking the anxiety-provoking cases into account. All these instruments were thought to help the researchers' cross-check the participant answers.

\section{Data Analysis}

In the data analysis process, the researchers followed a three-step In the data analysis process, the researchers followed a three-step analysis in which each data set was first separately analyzed and then all the data sets were crosschecked to compare similar and different answers. These three steps were;

- Individual analysis of each data set in which the answers of the participants to each instrument were separately checked in order to reach a clearer framework for the answers,

- In-group analysis in which the same data set was analyzed taking each participant's answers to the same instrument into account,

- Cross-group analysis in which the answers in different instruments were compared to each other in order to identify similar and different points in participant comments. 
The below table displays the three-step data analysis process:

Table 2. Summary of the three-step analysis process

\begin{tabular}{|l|l|l|}
\hline Steps & Process & Data sources \\
\hline $\begin{array}{l}\text { Step 1: Individual } \\
\text { analysis }\end{array}$ & $\begin{array}{l}\text { Separate analysis of the } \\
\text { data sets }\end{array}$ & $\begin{array}{l}\text { Diaries, field notes, peer- } \\
\text { observation forms, interviews }\end{array}$ \\
\hline $\begin{array}{l}\text { Step 2: In-group } \\
\text { analysis }\end{array}$ & $\begin{array}{l}\text { Comparing participant } \\
\text { answers in each set }\end{array}$ & $\begin{array}{l}\text { Diaries, field notes, peer- } \\
\text { observation forms, interviews }\end{array}$ \\
\hline $\begin{array}{l}\text { Step 3: Cross-group } \\
\text { analysis }\end{array}$ & $\begin{array}{l}\text { Comparing participant } \\
\text { answers across the data } \\
\text { sets }\end{array}$ & $\begin{array}{l}\text { Diaries, field notes, peer- } \\
\text { observation forms, interviews }\end{array}$ \\
\hline
\end{tabular}

Before conducting the main analysis process, the researchers carefully went through all the data sets following data reduction, data display and drawing conclusion steps (Miles \& Huberman, 1994). In this process, the researchers reached an initial code-forming, which was supported by the codes presented in previous literature on FLTA (Aydın, 2016; MacDonald, 1993; Paker, 2011). This initial analysis process was followed by the main three-step data analysis process as presented below.

Step 1: In the main data analysis process, the researchers first conducted individual analysis of each data set. In this step, the data sets were separately analyzed and recurring items common in different data sets were identified. The experiences of the participants were analyzed according to the stages in which they experienced FLTA (pre, while and post stages of teaching).

Step 2: In the second step, each data set was analyzed in detail through a comparison of participant comments to each other to identify similarities and differences in comments. This step was followed in order to find out whether similar codes were valid for each participant considering particular instruments.

Step 3: In the final step, a cross analysis of all the data sets were conducted in which the comments of the participants provided in different instruments were compared to each other. In this way, the participant comments and experiences were cross-checked to understand whether the same participant provided similar comments in different instruments. All these three steps involving in-group and cross-group comparisons of the data sets were followed to ensure trustworthiness in data analysis.

As regards the coding process, the researchers, in the light of existing literature on FLTA, divided the data into discrete parts and identified similar 
and different aspects in each data set. Then, data display was followed in order to summarize the data about the anxiety factors and coping strategies. In this process, a descriptive approach was followed to present participant experiences more clearly, involving participant quotations.

In the conclusion drawing step, the researchers compared the themes identified as a result of the analysis process to reach an understanding of the common experiences of the participants regarding FLTA. This comparison was done to ensure trustworthiness in the analysis process.

\section{Results}

Results obtained from the study show that EFL pre-service teachers experience FLTA before, after and during their teaching experiences. Furthermore, they employ various coping strategies to alleviate their anxieties. Table 1 shows the FLTA anxiety-provoking factors among EFL pre-service teachers and their coping strategies to overcome the anxiety problems before authentic teaching experience.

According to the findings shown in the table, there are five factors that may cause teaching anxiety. These are classroom management, fear of making mistakes, lack of teaching experience, time management, and establishing a good rapport with students. To overcome their anxiety problems, they employed 13 distinct coping strategies as reported by themselves and their peers.

\section{Anxiety sources before teaching events and pre-service teachers' coping strategies}

The following table shows the FLTA sources and the coping strategies reported by the participants before their authentic teaching experience. 
Table 3. Sources of FLTA reported and coping strategies employed prepracticum experience (data obtained from the three sources)

\begin{tabular}{|c|c|}
\hline \multicolumn{2}{|c|}{ Pre-practicum experience } \\
\hline Sources of FLTA & Coping strategies \\
\hline $\begin{array}{l}\text { Classroom management ( } 27) \\
38 \%\end{array}$ & $\begin{array}{l}\text { - consulting the mentor or cooperating teacher } \\
\text { (21) } \\
\text { - chatting with friends (15) }\end{array}$ \\
\hline $\begin{array}{l}\text { Fear of making mistake (16) } \\
23 \%\end{array}$ & $\begin{array}{ll}\text { - } & \text { practicing beforehand (14) } \\
\text { - } & \text { preparing many different materials (12) } \\
\text { - } & \text { preparing lesson plans (6) }\end{array}$ \\
\hline $\begin{array}{l}\text { Lack of practicum } \\
\text { experience (12) } 17 \%\end{array}$ & $\begin{array}{l}\text { - } \quad \text { practicing beforehand (9) } \\
\text { - } \quad \text { searching for examples of practicum } \\
\text { experiences from the internet (5) }\end{array}$ \\
\hline Time-management (9) 13\% & $\begin{array}{ll}\text { - } & \text { preparing lesson plans (7) } \\
\text { - } & \text { preparing many different activities (5) } \\
\text { - } & \text { practicing beforehand (4) }\end{array}$ \\
\hline $\begin{array}{l}\text { Establishing good rapport } \\
\text { with students (7) } 10 \%\end{array}$ & $\begin{array}{l}\text { - consulting mentor or cooperating teacher (4) } \\
\text { - chatting with friends (2) }\end{array}$ \\
\hline $\begin{array}{l}\text { Total: } 71(100 \%) \text { (the total } \\
\text { number of the items reported } \\
\text { by the participants) }\end{array}$ & \\
\hline
\end{tabular}

Firstly, as listed in Table 3, among the possible anxiety-generating factors before teaching experiences, the major concern of the pre-service teachers was about classroom management. Since they were not the real teachers for the student profile they were expected to teach, most of the participants expressed their anxiety about how to control a class full of unfamiliar learners. A participant, referring to classroom management as her biggest concern before she entered the classroom, stated that classroom management could be a problem for her since she was not the real teacher in the class: 
My biggest fear was about classroom management. I was not their real teacher; I was just like an elder-sister to them. So, I was anxious that I would not be able to set control over the students, which would negatively affect my teaching performance. (March 2017-from the diary)

Since potential cases creating classroom management problems were among the greatest concerns for the participants, most of the participants wanted to eliminate the negative effects of this problem before it happened. Consulting their mentors and cooperating teachers was one of the ways they tried to obtain some information to cope with management problems. Almost half of the participants also reported having rehearsed before their teaching practices to get as ready as possible for teaching and so that students would not detect gaps in their instruction, leading to management problems. Referring to the need for being prepared beforehand as a coping strategy in his comment, a participant, who expressed his high level of anxiety before the teaching events, provided the comment below:

Before teaching, I really become anxious and, mostly, I experience difficulty to control this. I am anxious about classroom management. I believe if I cannot control my fear, this would reflect itself in my performance. So, in order to overcome this problem, I try to benefit from the suggestions of my mentor and cooperating teacher because they are experienced in teaching. I also do practicing before my teaching event several times to get ready for it. In this way, if I am ready to teach, then students cannot find a way to conduct disruptive behaviors in my class. (April 2017-from the interview)

Secondly, as illustrated in Table 3, fear of making mistakes and lack of teaching experience were reported as the second major FLTA provoking source. The participants' comments revealed that there is a positive relationship between the fear of making mistakes and lack of teaching experience. Fear of making mistakes was frequently mentioned by the participants since they lacked necessary teaching experience through which they could get used to teaching and feel more relaxed. In addition, fear of making mistakes seemed to be both the cause and the consequence of teaching anxiety. In other words, the more the participants were afraid of making mistakes, the more their teaching anxiety increased; and the higher their teaching anxiety was, the more they suffered from the fear of making mistakes. Pointing at the relationship between her fear of making mistakes and the two-way connection between fear of making mistakes and teaching anxiety, a participant commented as follows:

I experience high levels of teaching anxiety because I don't have enough teaching experience and, therefore, I am afraid of making mistakes. I believe if I had enough practicum experience, I would have much more confidence in myself so I would not experience fear of anxiety at this level because I would know how to teach. The fear of making mistakes increases my anxiety. I think, 
my fear increases my anxiety and my anxiety increases my fear in turn. (March 2017- from the interview)

In order to overcome the fear of making mistakes and the drawback of her inexperience in teaching, the same participant also referred to some ways she used to minimize the negative impacts of anxiety:

I am aware of the points increasing my teaching anxiety, so I have developed some ways to deal with them. Since I lack practicum experience and I am afraid of making mistakes, I observed that practicing for the teaching events beforehand helps me overcome these challenges to a great extent. I also try to prepare lesson plans for many different activities so that I would experience fewer problems during teaching. (May 2017-from the diary)

Thirdly, as reported in Table 3, another concern which was also related to inexperience in teaching was time management. Some of the participants frequently mentioned time management as a possible problem in their teaching events. Since they were not used to controlling instruction time because of the lack of teaching experience, they were afraid that they would experience difficulty using the time appropriately. Considering time management as a challenge, a participant also referred to the coping strategies he benefitted from his teaching practices:

As I hadn't conducted a full lesson before, I was afraid I would not manage to fill the time up or I would finish the activities long before the break... In order to prevent the possible risk of time management, I tried to prepare detailed lesson plans and set time limitations with each step. I also prepared many different activities in case I had more time to fill up. And, I prepracticed the steps in my lesson plan so that I could get used to the process. (May 2017- from the interview)

Fourthly, as described in Table 3, establishing a good rapport with students is another FLTA source: the concern for some of the participants was having positive relationships with the students in their practice school experience. Though the participants were not the actual teachers of those students, they wanted to have a good rapport with the students, desiring to be considered as teachers. One of the participants shared the strategies she utilized to establish a good interaction with the students, underscoring the importance of this point for her:

We have been taught that if students love the teacher, they love the lesson. So, though I am an intern, I wanted to have a good relationship with the students in practice school. For this purpose, I consulted my cooperating teacher to learn her strategies about how to establish good relations with the students. Besides this, I sometimes talked with some friends to learn their experiences with the students. (April 2017- from the interview) 


\section{Anxiety sources while teaching events and pre-service teachers' coping strategies}

The Table 4 shows the FLTA sources and the coping strategies reported by the participants and their peers while authentic practicum experience.

Table 4. Sources of FLTA reported and coping strategies employed while practicum Experience

\begin{tabular}{|c|c|}
\hline \multicolumn{2}{|c|}{ While practicum experience } \\
\hline Sources of Anxiety & Coping strategies \\
\hline Mentor observation (32): $22 \%$ & $\begin{array}{ll}- & \text { ignoring being observed (27), } \\
\text { - } & \text { focusing on instruction/activities (22), } \\
\text { - } & \text { avoiding eye-contact with a mentor (18), } \\
\text { - } & \text { taking a deep breath, keep calm (17) }\end{array}$ \\
\hline $\begin{array}{l}\text { Classroom management (30): } \\
20 \%\end{array}$ & $\begin{array}{ll}\text { - } & \text { activating students (22), } \\
\text { - } & \text { ignoring disruptive behaviors (21), } \\
\text { - } & \text { eye-contact with students (19), } \\
\text { - } & \text { using body language (16), } \\
\text { - } & \text { dealing with problematic students } \\
& \text { individually (13), } \\
\text { - } & \text { keeping calm (11) }\end{array}$ \\
\hline Time management (27): $18 \%$ & $\begin{array}{l}\text { - } \quad \text { following lesson plan (23) } \\
\text { - } \quad \text { focusing on instruction/activities (19) }\end{array}$ \\
\hline $\begin{array}{l}\text { Fear of making mistakes (25): } \\
17 \%\end{array}$ & $\begin{array}{l}\text { - } \quad \text { following lesson plan (18), } \\
\text { - } \quad \text { focusing on instruction/activities (14) }\end{array}$ \\
\hline Teaching in English (21): 14\% & $\begin{array}{ll}- & \text { switching to Turkish (19), } \\
\text { - } & \text { interactive teaching (15) }\end{array}$ \\
\hline Voice control (13): $9 \%$ & $\begin{array}{ll}- & \text { body language }(9), \\
\text { - } & \text { smiling face }(6)\end{array}$ \\
\hline Total: $148(100 \%)$ & \\
\hline
\end{tabular}


Firstly, as seen in Table 4, being observed by a mentor, who was the faculty supervisor of the participants, was the most common concern among the participants: most of them reported that they felt more relaxed with teaching while they were alone with the students. In fact, the attendance of the mentor in their lessons increased their anxiety and this appears to have had a considerable impact on their psychological and sometimes physical control, which had a negative influence on their teaching performances. Declaring mentor observation as the main difficulty during his teaching performance, a participant maintained that he experienced actual tension with the mentor sitting in a chair in the back of the classroom observing his teaching:

Normally, I had a really good relationship with my mentor, and I felt comfortable communicating with her. But, when she came to observe my teaching, things changed. Suddenly, I realized that I was anxious because of her presence in the class. She was not doing anything negative. She was just sitting at the back and I knew she was there to provide some suggestions for us, but I couldn't help feeling anxious. I think being observed by my mentor was the most challenging part of the practicum for me. (March, 2017, -from the self-observation form)

To deal with the presence of a mentor observing them somewhere in the class, each participant developed different coping mechanisms like ignoring the presence of the mentor and cooperating teacher, avoiding eye-contact with them, taking a deep breath and keeping calm. Most of them utilized the ignoring strategy. They pretended that the mentor was not there, or s/he was one of the students. They also avoided having direct eye-contact with the mentor in order not to be affected by her/his non-verbal reactions. They mostly tried to take deep breaths and carry on with their teaching. Experiencing anxiety because of mentor observation, a participant commented that she tried to adapt different strategies to cope with this stress:

There was nothing I could to about the presence of my mentor. She was there to do her job. So, to deal with the anxiety caused by being observed, I tried to ignore the fact that I was being observed. I just pretended that I was alone in the class with the students. I also did not look directly into my mentor's eyes because I knew it would increase my anxiety. I just took a few deep breaths and did my best to keep on my lesson. (April 2017- from the diary)

As described in Table 4, the second main problem for the participants was classroom management, i.e., controlling students with disruptive behaviors. Since most of the pre-service teachers were young and inexperienced, they were sometimes challenged by students in practice schools. There were unexpected and unnecessary questions or some attempts to distract interns' or other friends' attention. These events had adverse effects on the participants' performances and increased their anxiety, which was clearly expressed by a 
participant who was distressed by management issues occurring in one of the classes she attended:

Before my teaching experience, I decided to be a lovely teacher for the kids and have fun with them during lessons. It worked well for most of the classes; however, there was a problematic class. You can't imagine how naughty they were. Almost all the students were talking and laughing unnecessarily not paying attention to the lesson and not

caring about the teacher. This distracted not only my attention but the interest of a few students who wanted to participate in the lesson. They were really making me anxious. I hope I won't have such students when I become a real teacher. (April 2017- from the interview)

Since classroom management was a serious issue, the participants tried to apply different methods to decrease, though not completely eliminate, the damaging effects of management problems. They noted that, if possible, they tried to motivate the students by drawing their attention to the lesson. When they could not get their desired attention, they either ignored the negative behavior or tried to warn the misbehaving student/s through direct eye-contact or nonverbal language. A participant provided some comments on the effectiveness of these ways in dealing with disruptive students:

There are misbehaving students in every class but what matters is the amount and intensity. As a pre-service teacher, I try to develop some ways to deal with management problems. For example, I try to attract students' attention and involve all of them in the class. When some students continue doing problematic behaviors, I approach them or

have eye-contact with them. If this does not work and there is nothing I can do, then I ignore them. What else can I do? (May 2017- from the interview)

Thirdly, as conveyed in Table 4, controlling the time allocated for their teaching practice was one of the challenges for most of the pre-service teachers. Since they did not have adequate experience in teaching, they experienced difficulty in adjusting for time: they occasionally finished their activities earlier and at other times, later than they had scheduled. Therefore, time management was a concern during their teaching performance; struggling with time management in the first few teaching events, a participant expressed that gaining experience is likely the solution for time management issues:

In the first three or four teaching events, I felt anxious about time management because I was either early or late to follow my plans. Therefore, I started to prepare more detailed lesson plans to follow during my teaching. I also tried to concentrate my and students' attention on instruction and activities to limit unnecessary interactions or acts. Now, I think, and my cooperating 
teacher says, I have better time control. The more experienced I become, the better time management skills I can have. So, time is the healer. (May 2017from the interview)

Fourthly, as shown in Table 4, fear of making mistakes, also felt before teaching events, was another problem experienced in the process of teaching. There appears to be two reasons why some of the participants were afraid of making mistakes: being observed by a mentor and being ridiculed by students. The participants did not want their mentor teachers to watch them making mistakes because it could negatively affect their evaluation. Wishing to be regarded as the real teachers of the students during the classes, they did not want students in practice schools to hear them making mistakes, either. Therefore, they felt the need to find some tactics to cope with this problem, as reported by a participant:

Among the other things, fear of making mistakes in front of the mentor and the students is a big problem. Of course, making mistakes is natural but still it is not good when you do it in front of the mentor or students. So, in order to avoid making mistakes, I try to stick to my lesson plan because I prepare lesson plans with every step-in detail. I also try to concentrate my full attention and students' attention on teaching and prefer to ignore everything else. (March 2017- from the interview)

As shown in Table 4, the language of instruction was considered a challenge for some of the participants. All the participants were attending secondary schools for their practicum practices and the course contents they were expected to teach were not advanced level topics. They experienced difficulty in adjusting the instructional language to the levels of the learners: since most of the students were elementary level learners, the participants sometimes found it difficult to use appropriate levels of instruction in English. Calling attention to this, a participant maintained that though the topic was easy, teaching it with simple items was difficult and he shared the tactics he utilized.

Before I taught the secondary school students, I thought that it would be easy to teach them because the topics were simple. However, when I began teaching, I realized that it was not as easy as I thought. Because though the topics were simple, it was challenging to teach them using the language they could understand. So, when I found it difficult to find simple phrases to teach, I sometimes switched to the native language,

Turkish. (April 2017- from the self-observation form) 
Finally, as shown in Table 4, another problem encountered in the comments of a few participants was voice control which is most probably related to the lack of teaching experience. Some of the participants stated that they were either speaking louder or quieter than they should and this negatively affected students' attention. Having some difficulties in voice management (e.g., loud or in a low voice), a participant shared the following experience and coping strategy:

When I feel anxious, I experience difficulty in controlling my voice. Since teaching practices are anxiety-generating situations; I can't help having some voice-control problems during my practices. Therefore, in order to deal with this problem, I try to integrate my body language into my instruction. (May 2017- from the interview)

\section{Anxiety sources after teaching events and pre-service teachers' coping strategies}

The following table shows the FLTA sources and the coping strategies reported by the participants and their peers <after?>authentic practicum experience. 
Table 5. Sources of FLTA reported and coping strategies employed postteaching Experience

\begin{tabular}{|l|l|}
\hline \multicolumn{2}{|c|}{ Post-practicum experience } \\
\hline \multicolumn{1}{|c|}{ Sources of Anxiety } & \multicolumn{1}{c|}{ Coping strategies } \\
\hline $\begin{array}{l}\text { Being evaluated/getting } \\
\text { feedback (35): } 29 \%\end{array}$ & $\begin{array}{l}\text { - considering feedback for development (29), } \\
\text { - asking a mentor for further advice (23) }\end{array}$ \\
\hline Being graded (34): $29 \%$ & $\begin{array}{l}\text { - asking for evaluation from mentor and } \\
\text { cooperating teacher (17) }\end{array}$ \\
\hline $\begin{array}{l}\text { Having good impact on } \\
\text { Having good impact on } 24 \% \\
\text { students (21): } 18 \%\end{array}$ & - having little chats with students (16) \\
\hline Total: $119(100 \%)$ & \\
\hline
\end{tabular}

In Table 5, almost all the participants experienced tension because they knew that they would be evaluated and provided with feedback based on their teaching performances. Most of them were concerned with receiving negative feedback from their mentors or cooperating teachers, thinking that it would decrease their self-confidence. Appreciating the importance of feedback for future performances, a participant referred to his fear of negative evaluation and explained that he would be influenced by the content of feedback:

Getting feedback on our teaching performances is beneficial for us to develop ourselves. However, no one wants to be criticized. So, receiving negative feedback, though it is true, may decrease my self-confidence and motivation leading me to think that I don't have the capabilities to be an English teacher. (March 2017- from the interview)

Experiencing this anxiety, some participants also developed ways to deal with this stress. There were two key solutions the participants mentioned: considering feedback as a tool for development and asking mentors to provide further advice. A participant underlined the necessity to receive feedback on the following:

It is not just enough to stand in front of the students, teach them and leave the class. In order to become better teachers, we need to be aware of our strengths and weaknesses. At this point, being evaluated by our 
mentors and cooperating teachers is advantageous for us. Since they are professionals, they can think of the points that we cannot see... Receiving feedback may not always be so desirable but still, we need to see it as a chance for professional development. (April 2017- from the diary) in Table 5, being graded for their performances created concern and anxiety for most of the participants.

Though they were prospective teachers, they were still students and getting high marks was therefore important for them. Experiencing frequent concern from being graded, a participant shared her thoughts:

I try to do my best in all courses and, to be honest, I want to get high marks. This is also valid for teaching practicum. Here, we are evaluated and graded according to our teaching performances and I often have the fear of getting low marks in practicum. (March 2017- from the interview)

The participants referring to the anxiety caused by being graded did not mention any strategies to cope with this anxiety source. As shown in Table 5 , the experience of being observed by a mentor who has more professional experience was reported to increase the participants' desire to have a good impact on the mentor. As the mentor is the source of feedback as well as grading, pleasing the mentor may be a priority for the participants. With this in his mind, a participant explained that he wanted to please the mentor:

The mentor is the one to evaluate us and to give grades on our performances; so, it is important to leave a good impression on the mentor. (March 2017- from the interview)

There were no specific suggestions provided by the participants regarding the way to deal with the concern to have a good impact on mentors. They implicitly referred to asking mentors or cooperating teachers for additional evaluation on their performances to further assess their perceptions of their teaching.

Finally, as shown in Table 5, more than half of the participants considered having a good impact on the students in the practicum school as an important aspect of their teaching. They expressed their desire to teach something to the kids and be role-models. Sharing her wish to be part of good memories for her students, a participant stated that she was having little chats with the kids to understand whether they liked her or not: 
Being a teacher is a perfect feeling. During my practices, I tried to follow the idea that we need to be with students and not against them. I believed we could add something to them in this way. And, I wondered whether I could accomplish this. So, I was sometimes asking them questions about my teaching or approach. Luckily, it seems I could do it. (May 2017from the interview)

In conclusion, there were different sources of stress for pre-service teachers affecting their anxiety levels before, during and after teaching events ranging from educational to individual issues. Therefore, the existence of these problems inevitably directed the participants to search for some ways to cope with the challenges and to increase their motivation and the quality of their performance.

\section{Discussion and Conclusions}

The results of this study pointed at the following conclusions to be discussed. The first conclusion is that FLTA was experienced in the before, during and after stages of the teaching experience. This result was in line with those reported in much of the previous research proposed by Aydin (2016) and Sammephet and Wanphet (2013). This overall conclusion can reveal that the pre-service teachers are under the influence of different factors resulting in FLTA in all phases of the teaching practicum.

The second conclusion has to do with the factors causing anxiety for the participants. Regarding their before teaching experience, the participants reported being negatively affected by the concerns of classroom management, fear of making mistakes, lack of teaching experience, time management, and establishing a good rapport with students. These concerns were also mentioned as anxiety-provoking factors by Lampadan (2014), Machida (2016), Merç (2011) and Paker (2011). Considering the actual teaching phase of the teaching experience, the participants noted that mentor observation, classroom management, time management, fear of making mistakes, teaching in English and voice control were the reasons why they felt FLTA. Similar causes of FLTA felt during the teaching experience were also reported by Kim and Kim (2004), Merç (2015) and Sammephet and Wanphet (2013). Interestingly, classroom management before and during teaching experience other than factors related to language (e.g., making mistakes and proficiency) are frequently reported as a FLTA factor in research conducted in Turkish and Thai contexts (Lampadan, 2014; Mahmoudi \& Özkan, 2016, Merç, 2011). Additionally, being observed has been frequently reported as a teaching anxiety-provoking factor in previous studies conducted in Turkish, Thai and Indonesian contexts (Agustina, 2014; Aydın, 2016; Azmi, 2012; Sammephet \& Wanphet, 2013). As for their after teaching experiences, the participants expressed that they were under the effect 
of anxiety caused by getting feedback from mentors, being graded, hesitations on having a positive impact both on students and mentors, which echoes the results reported by Merç (2011).

The third conclusion is related with the coping strategies employed by the participants. The participants were observed to adapt distinct coping strategies with an aim to overcome the FLTA problems they encountered in different stages of the teaching experience (e.g., 13 strategies before the teaching experience, 18 strategies during the teaching experience and 4 strategies after the teaching experience). While previous research has reported that communication, establishing clear goals, relaxation techniques (MacDonald, 1993), anxiety management tactics like self-control, accepting and facing the situations (Sammephet \& Wanphet, 2013), adaption and developing positive attitudes (Lampadan, 2014) are the main coping strategies employed by pre-service teachers, our study showed that the Turkish pre-service teachers employed a wide range of coping strategies, from consulting, to mentorship, to receiving advice and practicing taking deep breaths and switching to L1.

In light of these results, we can conclude firstly that fear of making mistake is also a factor that is comparable to foreign language anxiety, apart from FLTA. This conclusion can be reached based on the participant experiencing referring to the factor of fear of making mistakes, as both the cause and the result of the teaching experience: the participants' having the fear of making mistakes caused them to experience teaching anxiety and this in turn negatively affected their teaching performance increasing the level of being afraid of making mistakes. Secondly, pre-service teachers can experience different types of FLTA in each of their before, during and after teaching experience (Aydin, 2016; Sammephet \& Wanphet, 2013). Thirdly, teaching in English caused the participants to experience FLTA. This may indicate that the profession may become even more difficult for non-native language teachers who are supposed to teach a language which is not their own language (Merç, 2011; Yoon, 2012). Fourthly, the participants reported having a lack of experience and being observed by their mentors caused FLTA. As stated in the previous research literature, these factors can cause anxiety for pre-service teachers and may sometimes have severe consequences on their attitudes towards the profession (Kim \& Kim, 2004; Merç, 2014, 2015; Sammephet \& Wanphet, 2013). Fifthly, classroom management was also found to be a common factor causing FLTA in this study. This may have stemmed from crowded classrooms, as also reported by Merç (2004), due to the difficulties of classroom management in such large classes. We should note however that in a study by Aydin (2016) it was reported that the pre-service teachers polled did not perceive any problems related to crowded classrooms. Sixthly, although Yoon (2012) found that lack of self-confidence is a factor in FLTA, the findings of the present study is complementary with those of Aydin's (2016), in as much as the participants did not report the lack of confidence as an FLTA factor. 
The conclusions reached in the present study suggests that first and foremost, as the pre-service teachers need more training on practical strategies on how to cope with their FLTA problems, the raising awareness of FLTA and strategy training topics should be embedded in the teacher training curricula. In such a process, the issue of training the faculty also becomes essential as the faculty do not receive formal training on how to conduct the process of practicum. Therefore, with the aim to prepare the pre-service teachers for the possible challenges awaiting them, the faculty should receive formal training regarding effective mentoring. Secondly, although some anxiety-provoking factors such as fear of making mistakes, classroom management and time management can be observed in most of the inexperienced in-service teachers, other superfluous factors such as mentor observation and being graded can only be observed in pre-service training programs. If such superfluous FLTA factors can be eliminated through creating authentic teaching settings, the preservice teachers can more easily focus on the act of teaching and alleviate their FLTA and employ common coping strategies; otherwise, they may always try to be perfect by avoiding making mistakes. However, as Aydin (2016) suggested, if teachers are made to understand that making mistakes is a natural part of the teaching process, it is possible to eliminate such an FLTA source by eliminating the attempts at perfectionism and by being realistic with situations that contribute to teachers making mistakes. Therefore, again it can be suggested that the courses in the undergraduate programs should be designed and conducted in a way to train pre-service teachers, who can seek to do their jobs as best while understanding that they are also human beings who may naturally make mistakes. In this way, we propose that the negative effects of the anxiety created by being observed or graded should naturally decrease.

The results of this study were in line with those reported in existing research on FLTA. However, as this research was grounded on qualitative basis and conducted with comparatively limited number of participants, the issue of generalizability requires further discussion since the number of participants, the student profiles in the practicum experience as well as the context in which the study is conducted, can influence the results of the study.

The study was limited to $29 \%$ male and $71 \%$ female for a total of 32 participanting pre-service teachers of English from two different universities. This reflects the overall male and female rate in the English Language 76 Teaching Departments. This gender-based limitation portends to an area of future research, where a more balanced gender-based participation could be beneficial. Moreover, the study collected data from qualitative sources such as diaries, open-ended questions, and interviews; to understand deeply the issue of FLTA, other techniques such as concurrent data collection with think-aloud protocols should be used in further research. 
In conclusion, this study discussed a facet of FLTA in EFL teacher training in Turkey, and it raised important issues for EFL teacher training programs in Turkey in terms of aligning pre-service teacher education with the students' needs when it comes to teaching skills and training mentors to help them eliminate their FLTA problems in actual field teaching contexts. Further, it can be suggested for mentors that they can present confidencebuilding opportunities in classrooms such as in-front-of-class presentations and assignments (e.g., interviews, text analysis and mock televised news presentations) as initial ingredients in the FLTA-combatting recipe. 


\section{References}

Agustiana, V. (2014). Pre-service teachers' anxiety during teaching practicum. English Review: Journal of English Education, 2(2), 174-182.

Arthur, J., Waring, M., Coe, R., \& Hedges, L.V. (2012). Research Methods \& Methodologies in Education. Thousand Oaks, CA: Sage Publications.

Aydin, S. (2008). An investigation on the language anxiety and fear of negative evaluation among Turkish EFL learners. Asian EFL Journal, 30(1), 421444.

Azmi, M. (2012). Teaching English and stress: Teacher trainees vs. experienced teachers. Asian Transactions on Basic and Applied Sciences, 2(5), 30-39.

Aydin, S. (2016). A qualitative research on foreign language teaching anxiety. The Qualitative Report, 21(4), 629-642.

Brown, H. D. (2000). Principles in language learning and teaching. New York: Pearson Education Company.

Elald1, Ş. (2016). Foreign language anxiety of students studying English Language and Literature: A Sample from Turkey. Educational Research and Reviews, 11(6), 219-228.

Flick, U. (2018). Managing Quality in Qualitative Research. Los Angeles: Sage.

Gal, N. (2006). The role of Practicum supervisors in behavior management Education. Teaching and Teacher Education, 22, 377-393.

Gardner, L. \& Leak, G. (1994). Characteristics and correlates of teaching anxiety among college psychology teachers. Teaching of Psychology, 21 (1), 28-32.

Gopang, I., Bughio, F., \& Pathan, H. (2015). Investigating foreign language learning anxiety among students learning English in a public sector university, Pakistan. The Malaysian Online Journal of Educational Science, 3(4), 27-37.

Gregersen T, Meza, MZ, MacIntyre, P.D (2014). The motion of emotion: Idiodynamic case studies of learners' foreign language anxiety. The Modern Language Journal, 98(2), 574-588.

Han, T. \& Aybirdi, N. (2017). Turkish EFL students' perspectives regarding responsibilities in reducing foreign language classroom anxiety (pp.115126). In Researching ELT: Classroom Methodology and Beyond (Ed. Dinçay Köksal). Frankfurt am Main ; New York : Peter Lang 
Hellström, Nolan, \& Lundh (2005). "We do things together" A case study of "couplehood" in dementia. Dementia, 4(1), 7-22.

Horwitz, E. K., Horwitz, M. B., \& Cope, J. A. (1986). Foreign language classroom anxiety. The Modern Language Journal, 70(2), 125-132. http:// dx.doi.org/10.2307/327317.

Kesen, A., \& Aydin, Z. (2014). Anxiety levels of novice and experienced EFL instructors: Istanbul Aydın University case. Procedia - Social and Behavioral Sciences, 116, 880-883. doi:10.1016/j.sbspro.2014.01.314.

Kim, S. Y., \& Kim, J. H. (2004). When the learner becomes a teacher: Foreign language anxiety as an occupational hazard. English Teaching, 59(1), 165185.

Lampadan, N. (2014). Understanding the causes of anxiety and coping strategies of student teachers during their internship: A phenomenological study. Catalyst, 10(2), 34-45.

MacDonald, C. (1993). Coping with stress during the teaching practicum: The student teacher's perspective. The Alberta Journal of Educational Research, $39,407-418$.

Machida, T. (2016). Japanese Elementary School Teachers and English Language Anxiety. TESOL Journal, 7(1), 40-66.

Mahmoudi, F. \& Özkan, Y. (2016). Practicum stress and coping strategies of pre-service

English language teachers. Procedia - Social and Behavioral Sciences, 232, 494-501. https://doi.org/10.1016/j.sbspro.2016.10.067.

Merç, A. (2004). Reflections of pre-service EFL teachers throughout their teaching practicum: What has been good? What has gone wrong? What has changed? (Unpublished master's thesis). Anadolu University, Eskişehir, TR.

Merç, A. (2011). Sources of foreign language student teacher anxiety: A qualitative inquiry. Turkish Online Journal of Qualitative Inquiry, 2(4), 80-94. Retrieved from http://www.dergipark.ulakbim.gov.tr/tojqi/article/ view/5000093463.

Merç, A. (2015). Foreign language teaching anxiety and self-efficacy beliefs of Turkish preservice EFL teachers. The International Journal of Research in Teacher Education, 6(3),40-58.

Oxford, R. L. (1999). Anxiety and the language learner: new insights. In J. Arnold (Ed). Affect in language learning. Cambridge: CUP. 
Paker, T. (2011). Student teacher anxiety related to the teaching practicum. Egitim Arastirmalari-Eurasian Journal of Educational Research, 42, 207224.

Sammephet, B., \& Wanphet, P. (2013). Pre-service teachers' anxiety and anxiety management during the first encounter with students in EFL classroom. Journal of Education and Practice, 4(2), 78-87.

Scovel, T. (1978). The effect of affect on foreign language learning: A review of the anxiety research. Language Learning, 28(1), 129-142. https://doi. org/10.1111/j.1467-1770.1978.tb00309.x

Smith, K. (2010). Assessing the Practicum in teacher education-Do we want candidates and mentors to agree? Studies in Educational Evaluation, 36, $36-41$.

Stake, R. E. (1995). The art of case study research. Thousand Oaks, CA: Sage

Strauss, A. \& Corbin, J. (1990) Basics of Qualitative Research: Grounded Theory Procedures and Techniques. Newbury Park, CA: Sage Publications.

Walliman, N. (2011). Research Methods: The Basics. Routledge

Wolcott, H.F. (1994). Transforming qualitative data: Description, analysis, and interpretation. Thousand Oaks, CA: Sage.

Yoon, T. (2012). Teaching English through English: Exploring anxiety in nonnative preservice ESL teachers. Theory and Practice in Language Studies, 2(6), 1099-1107. http://doi.org/10.4304/tpls.2.6.1099-110 


\section{Authors}

* Dr. Turgay Han is an associate professor at the Department of English Language and Literature, Faculty of Letters of Ordu University (2016-continue). He also worked at Kafkas University between 2006 and 2016. His areas of research center on EFL measurement and assessment issues, linguistics, language learning and teaching.

ORCID: https://orcid.org/0000-0002-9196-0618

Ayşegül Takkaç Tulgar is an Assistant Professor in the English Language Teaching Department, Atatürk University, Turkey. She is interested in pre-service education, glocalization in education, and teaching Turkish as a second language.

ORCID: https://orcid.org/0000-0001-6401-969X 


\section{Appendix}

\section{Date of Observation:}

\begin{tabular}{|c|c|c|c|}
\hline \multicolumn{4}{|l|}{ A. Experiences before taking the class } \\
\hline & Observed & $\begin{array}{c}\text { Not } \\
\text { observed }\end{array}$ & Comment: \\
\hline \multicolumn{4}{|l|}{$\begin{array}{l}\text { The problems encountered before } \\
\text { taking the class and the strategies to } \\
\text { overcome them. }\end{array}$} \\
\hline \multicolumn{4}{|l|}{$\begin{array}{l}\text { Other problems causing anxieties } \\
\text { (e.g., lesson plan, classroom } \\
\text { management, language proficiency, } \\
\text { etc.) }\end{array}$} \\
\hline \multicolumn{4}{|l|}{ B. Experiences during the class. } \\
\hline \multicolumn{4}{|l|}{$\begin{array}{l}\text { How were the anxiety provoking } \\
\text { situations reported prior to the taking } \\
\text { class overcome? }\end{array}$} \\
\hline \multicolumn{4}{|l|}{$\begin{array}{l}\text { Did you realize the difficulties you } \\
\text { might have had before the lesson? } \\
\text { (What has happened?) }\end{array}$} \\
\hline \multicolumn{4}{|l|}{$\begin{array}{l}\text { What were the biggest challenges } \\
\text { faced in his first class (classroom } \\
\text { management, linguistic competence, } \\
\text { adjusting time, fear of making } \\
\text { mistakes, following the lesson plan, } \\
\text { supervisor observation, etc.)? }\end{array}$} \\
\hline \multicolumn{4}{|l|}{$\begin{array}{l}\text { How did you deal with these } \\
\text { problems? } \\
\text { What did you do when he realized } \\
\text { that he was unable to carry out his } \\
\text { lesson as he planned in advance? }\end{array}$} \\
\hline $\begin{array}{l}\text { What did you do when you realized } \\
\text { that he had made a mistake in } \\
\text { describing the lesson? }\end{array}$ & & & \\
\hline
\end{tabular}




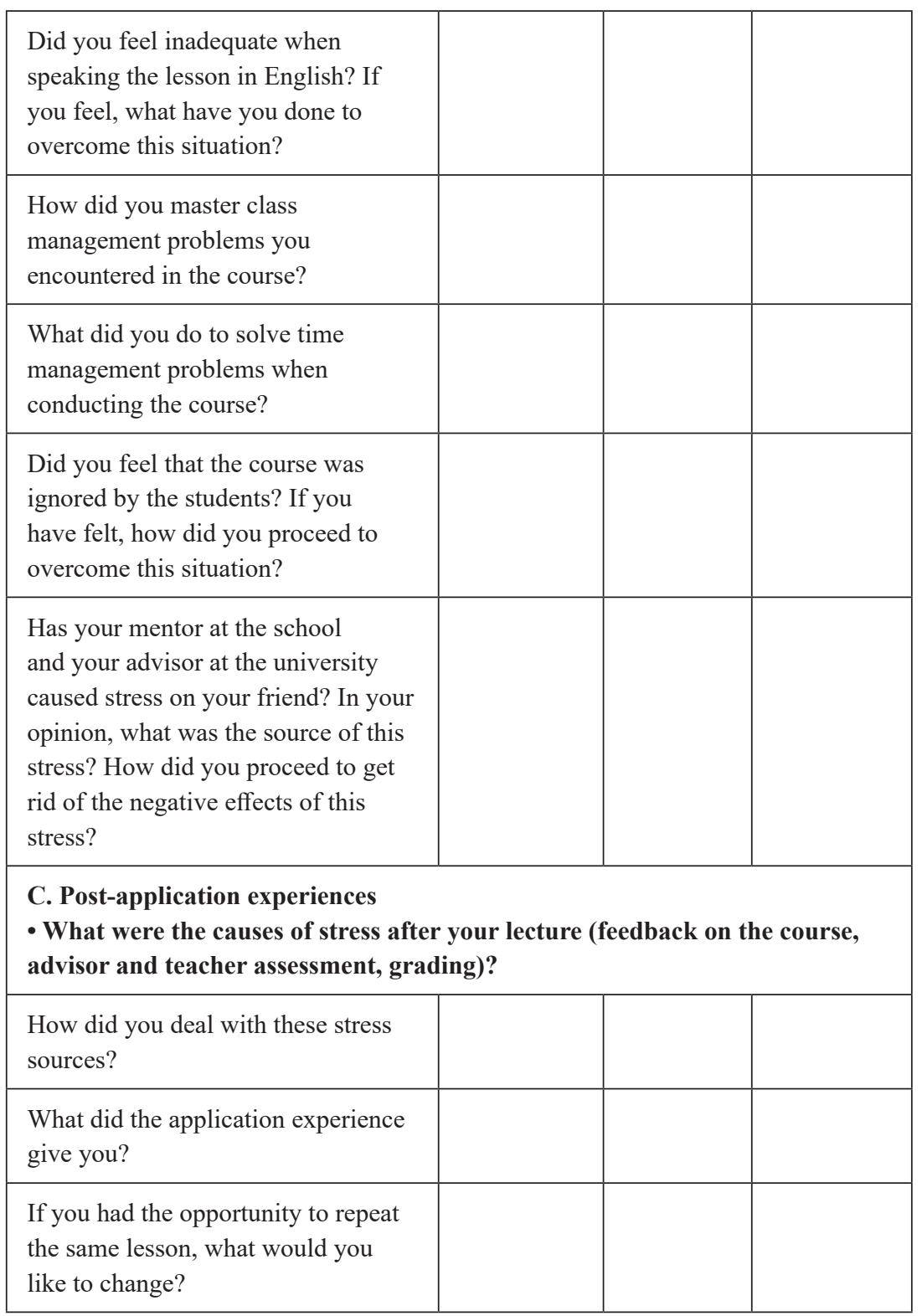

How to reference this article: Han , T., \& Takkaç-Tulgar, A. (2019). Analysis of the pre-service teachers' teaching anxiety and coping strategies: A Turkish Elementary School Context. GIST - Education and Learning Research Journal, 19, 49-83. https://doi.org/10.26817/16925777.802 